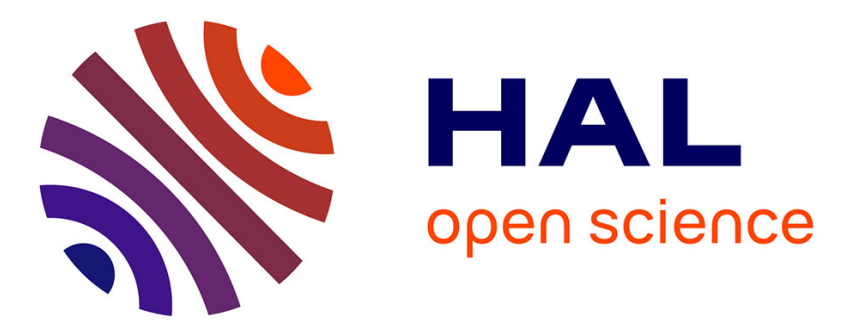

\title{
Fission products and nuclear fuel behavior under severe accident conditions Part 2: Fuel behavior in the VERDON-1 sample
}

E. Geiger, Le Gall Claire, A. Gallais-During, Yves Pontillon, J. Lamontagne, Eric Hanus

\section{To cite this version:}

E. Geiger, Le Gall Claire, A. Gallais-During, Yves Pontillon, J. Lamontagne, et al.. Fission products and nuclear fuel behavior under severe accident conditions Part 2: Fuel behavior in the VERDON-1 sample. Journal of Nuclear Materials, 2017, 495, pp.49-57. 10.1016/j.jnucmat.2017.08.002 . cea02388727

\section{HAL Id: cea-02388727 https://hal-cea.archives-ouvertes.fr/cea-02388727}

Submitted on 2 Dec 2019

HAL is a multi-disciplinary open access archive for the deposit and dissemination of scientific research documents, whether they are published or not. The documents may come from teaching and research institutions in France or abroad, or from public or private research centers.
L'archive ouverte pluridisciplinaire HAL, est destinée au dépôt et à la diffusion de documents scientifiques de niveau recherche, publiés ou non, émanant des établissements d'enseignement et de recherche français ou étrangers, des laboratoires publics ou privés. 


\title{
Fission products and nuclear fuel behavior under severe accident conditions \\ Part 2: Fuel behavior in the VERDON-1 sample
}

\author{
E. Geiger*, C. Le Gall, A. Gallais-During, Y. Pontillon, J. Lamontagne, E. Hanus, G. Ducros \\ CEA, DEN, DEC, F-13108 Saint-Paul-lez-Durance, France
}

Within the frame of the International Source Term Program, VERDON program aims at quantifying the source term of radioactive materials in case of a hypothetical severe accident in a Light Water Reactor (LWR). Tests were performed in a new experimental laboratory (VERDON) built in the LECA-STAR facility (CEA Cadarache). The VERDON-1 test was devoted to the study of a high burn-up $\mathrm{UO}_{2}$ fuel and FP release at very high temperature $\left(\approx 2600^{\circ} \mathrm{C}\right)$ under reducing atmosphere. Post-test qualitative and quantitative characterizations of the VERDON-1 sample led to the proposal of a scenario explaining what might have occurred during the experimental sequence. Hence the fuel and the cladding might have interacted leading to the melt of $\mathrm{UO}_{2}-\mathrm{ZrO}_{2}$ system. Besides no relocation was observed during the test, it might have been imminent.

\section{INTRODUCTION}

Within the frame of the International Source Term Program, different tests were performed in the VERDON laboratory at the LECA-STAR facility (CEA Cadarache). Their objective was to quantify the source term of LWR in case of a hypothetical severe accident. More precisely, the VERDON-1 test was devoted to high burn-up $\mathrm{UO}_{2}$ fuel behavior and FP release under reducing conditions at very high temperature (up to $2610^{\circ} \mathrm{C}$ ).

In this work, a detailed characterization including Scanning Electron Microscopy (SEM) and Optical Microscopic (OM) observations as well as Electron Probe MicroAnalyses (EPMA) of the VERDON-1 sample before and after the test is given. A special focus is made on the different chemical phases found into the fuel and a scenario explaining the evolution of the fuel during the test is proposed. The VERDON-1 experimental circuit and the progress of the accidental thermal-hydraulic sequence are briefly summarized as it has been extensively discussed in a first article [1].

\section{FUEL SAMPLES CHARACTERISTICS}

\subsection{VERDON-1 father rod}

The father rod from which the VERDON-1 sample was extracted has been irradiated for six cycles in a Nuclear Power Plant (NPP) operated by EDF. The mean burn-up of the rod

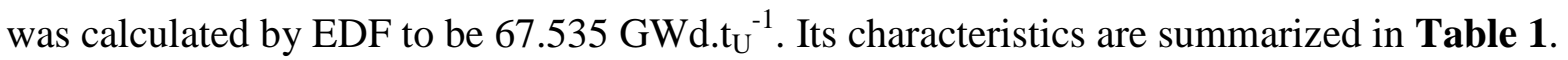


Table 1: VERDON-1 father rod characteristics

\begin{tabular}{cccccc}
\hline $\begin{array}{c}\text { Cladding } \\
\text { material }\end{array}$ & $\begin{array}{c}\text { Outer diameter } \\
\text { of clad }(\mathbf{m m})\end{array}$ & $\begin{array}{c}\text { Inner diameter of } \\
\text { clad }(\mathbf{m m})\end{array}$ & Fuel & $\begin{array}{c}\text { Pellets mean } \\
\text { height }(\mathbf{m m})\end{array}$ & $\begin{array}{c}\text { Pellets mean } \\
\text { diameter }(\mathbf{m m})\end{array}$ \\
\hline $\mathrm{M} 5$ & 9.50 & 8.25 & $\mathrm{UO}_{2}$ & 13.65 & 8.086 \\
\hline
\end{tabular}

SEM and EPMA were performed at the periphery of the fuel in contact with the cladding, at half diameter from the periphery and at the center of the pellet. This allowed an accurate description of the overall fuel sample before the VERDON-1 test.

SEM observations were performed using a Philips XL30 device. Large field acquisitions were performed using the ADDA SIS system and the AnalySIS software was used for images analyses.

Concerning EPMA, a shielded CAMECA SX100R device was used for acquisition and exploitation of the measurements. Incident electron beam characteristics were set at $20 \mathrm{kV}$ and $200 \mathrm{nA}$.

At the periphery, the High Burn-up Structure (HBS) has been observed [2]-[4]. It extends in a ring up to $60 \mu \mathrm{m}$ from the periphery. This restructuration is characterized by the presence of small round and polyhedral sub-grains and a dense concentration of pores which sizes vary from 0.4 to $2 \mu \mathrm{m}$. A fractography of this region is presented on Figure 1.

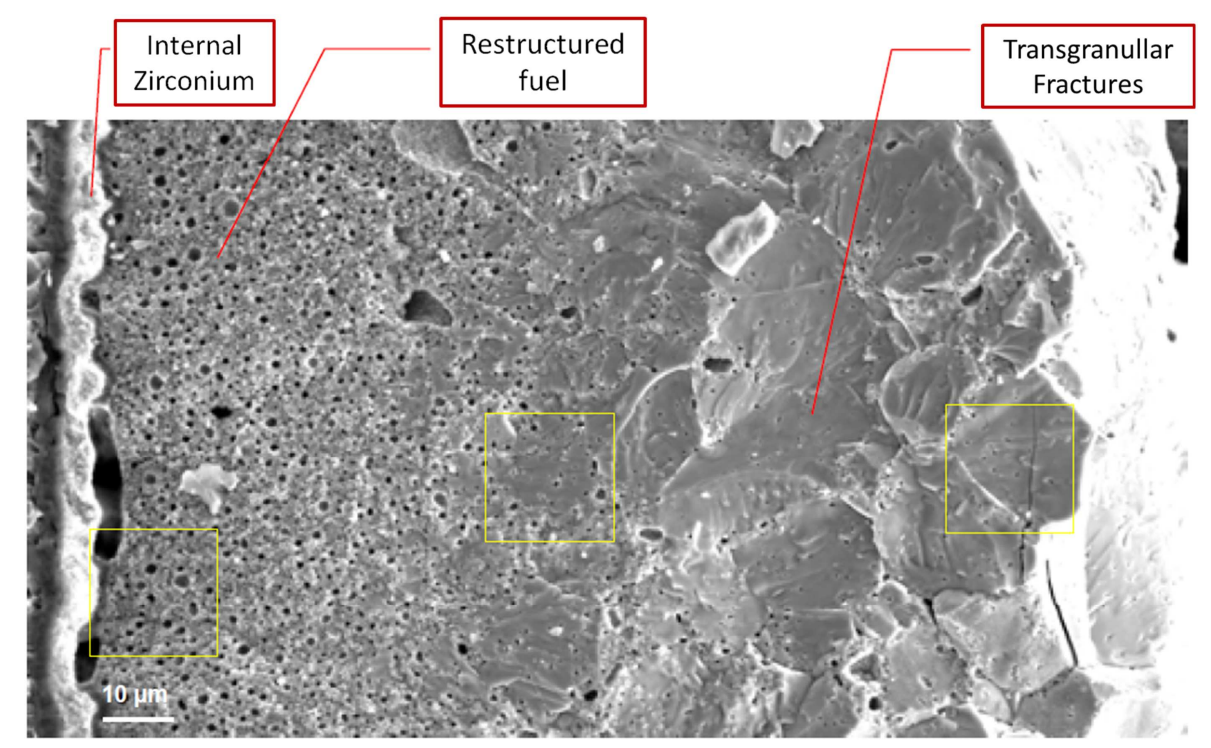

Figure 1: Fractography of the pellet periphery, VERDON-1 father rod

EPMA were performed on a polished cross-section of a pellet, from the periphery up to the center. Close to the periphery, higher $\mathrm{Pu}$ and $\mathrm{Nd}$ contents, 4.3 and $1.5 \mathrm{wt} \%$ respectively, have been noticed coinciding with the HBS. Their concentration decreases down to 1 and $0.7 \mathrm{wt} \%$ respectively around $800 \mu \mathrm{m}$ from the periphery up to the center of the sample (Figure 2). According to $\mathrm{Nd}$ concentration, the local burn-up was estimated to be 150 GWd.t ${ }^{-1}$ in the HBS region. 


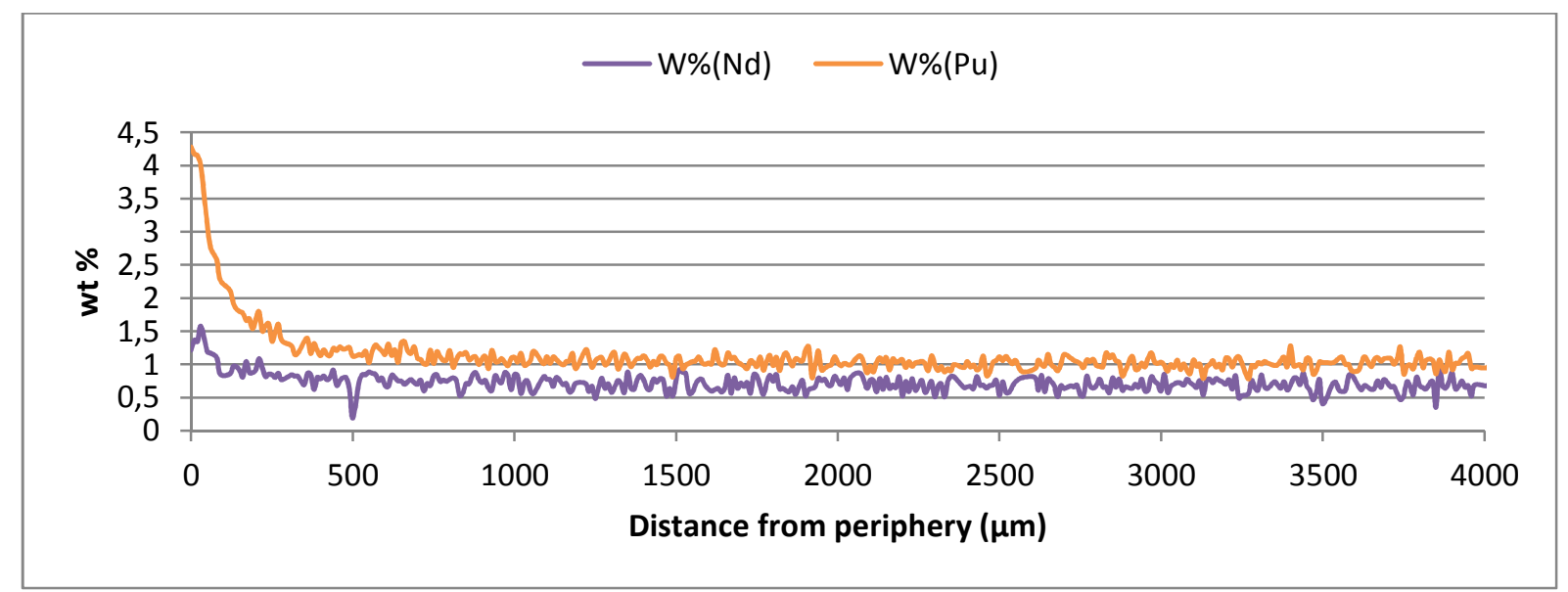

Figure 2: Pu and Nd radial EPMA quantitative profiles, VERDON-1 father rod

Small precipitates of diameter from 0.2 to $1 \mu \mathrm{m}$ were found mainly between the center and $2500 \mu \mathrm{m}$ from the edge of the pellet (Figure 3). Their density is more elevated at the periphery and in the center than in the half diameter region of the sample. As shown thanks to quantitative profiles obtained by EPMA (Figure 4), these precipitates are composed of Mo being the main constituent, Ru and Pd. They are common in irradiated nuclear fuels [5].

Beside the elevated density of metallic precipitates in the center of the fuel pellets, an important inter-granular porosity was also observed with a pores size of about $1 \mu \mathrm{m}$.

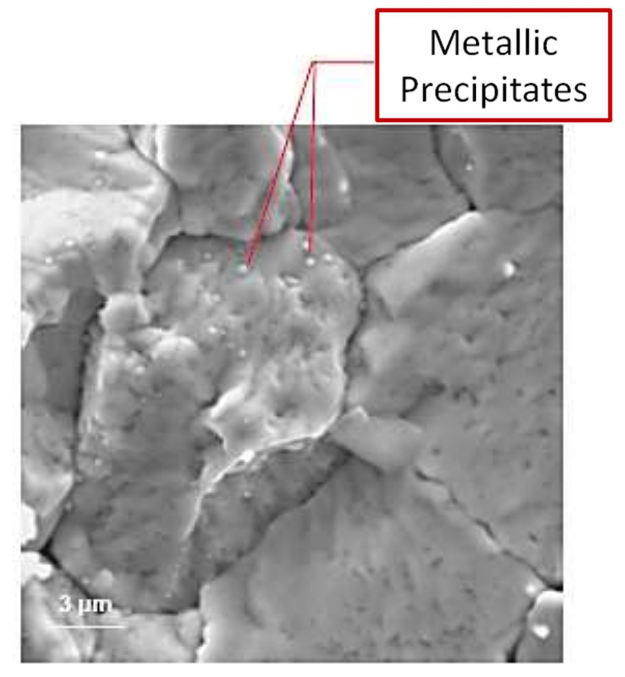

Figure 3: SEM image of Mo, Ru, Pd, Tc and Rh metallic precipitates, VERDON-1 father rod 


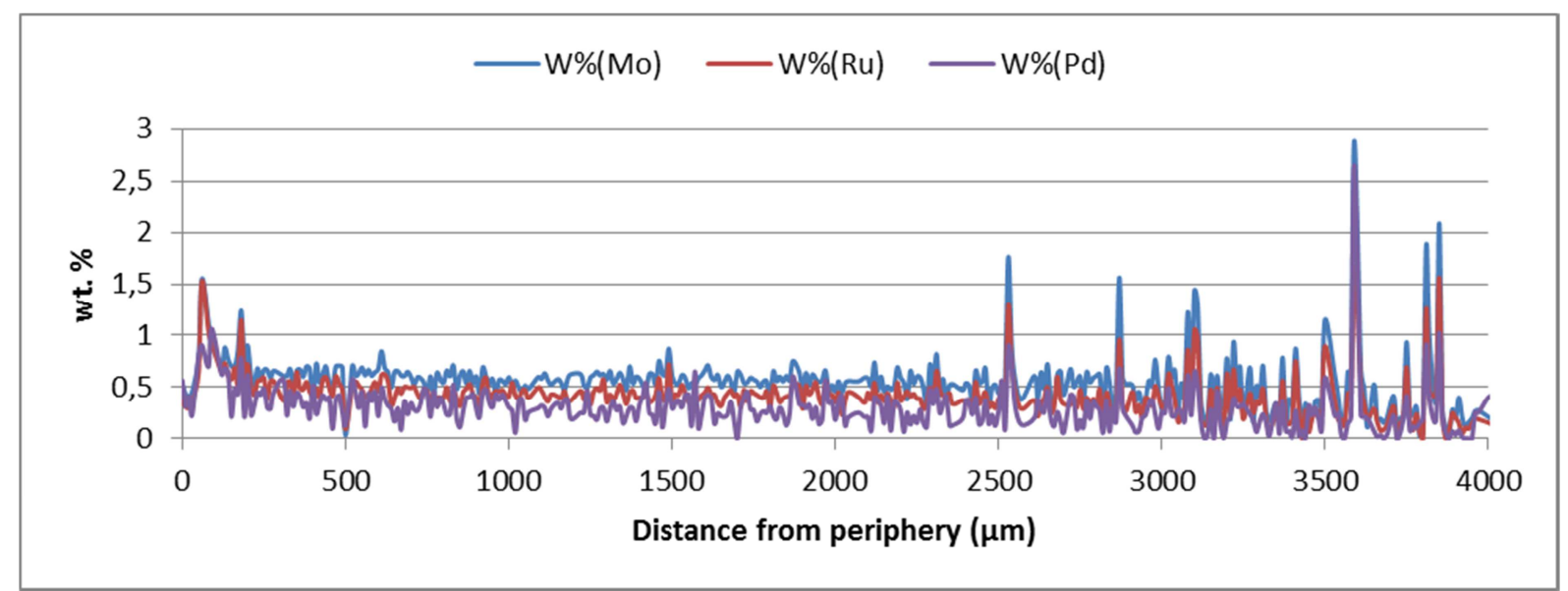

Figure 4: Mo, Ru and Pd radial EPMA quantitative profiles, VERDON-1 father rod

The fractography and Cs X-ray map presented on Figure 5 reveal the presence of cesium precipitates at half-diameter of the pellet. No association was observed between cesium and molybdenum or tellurium. No such precipitates were observed in the same region during the EPMA analysis of a polished sample. It was assumed that these precipitates had been eliminated during the preparation of the sample. Small bubbles of xenon, not shown in this paper, were also observed in this region, with a diameter between 0.1 and $0.2 \mu \mathrm{m}$.

$\mathrm{Xe}$ and Cs quantitative radial profiles are presented on Figure 6. The Xe creation quantity has been estimated from $\mathrm{Nd}$ quantitative analyses fitted with the following equation [6]. A correction corresponding to the creation ratio $\mathrm{Xe} / \mathrm{Nd}$ has been applied.

$$
I=A e^{-\alpha x / R}+B e^{-\beta x / R}+C
$$

The Xe signal is lost both at the periphery, coinciding to the HBS zone, and in the center of the sample. These gaps can be explained on the one hand by the release of gaseous $\mathrm{Xe}$ during irradiation in the reactor and on the other hand by the escape of gaseous Xe during polishing. On the contrary, Cs content is higher at the periphery $(0.75 \mathrm{wt} \%)$ and decreases down to $0.4 \mathrm{wt} \%$ in the center.
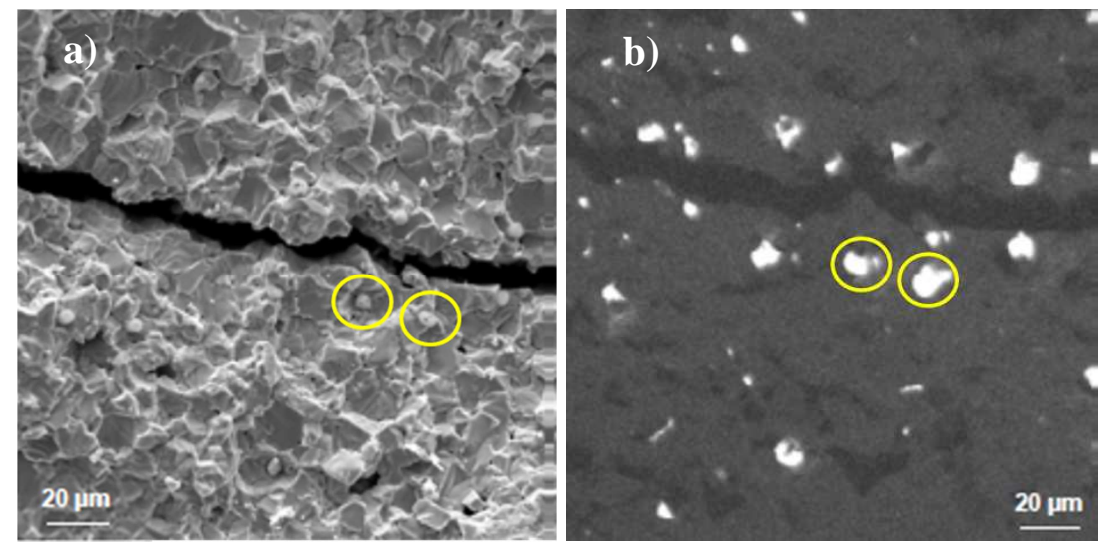

Figure 5: a) SEM fractography and b) Cs X-ray map, half-diameter, father rod 


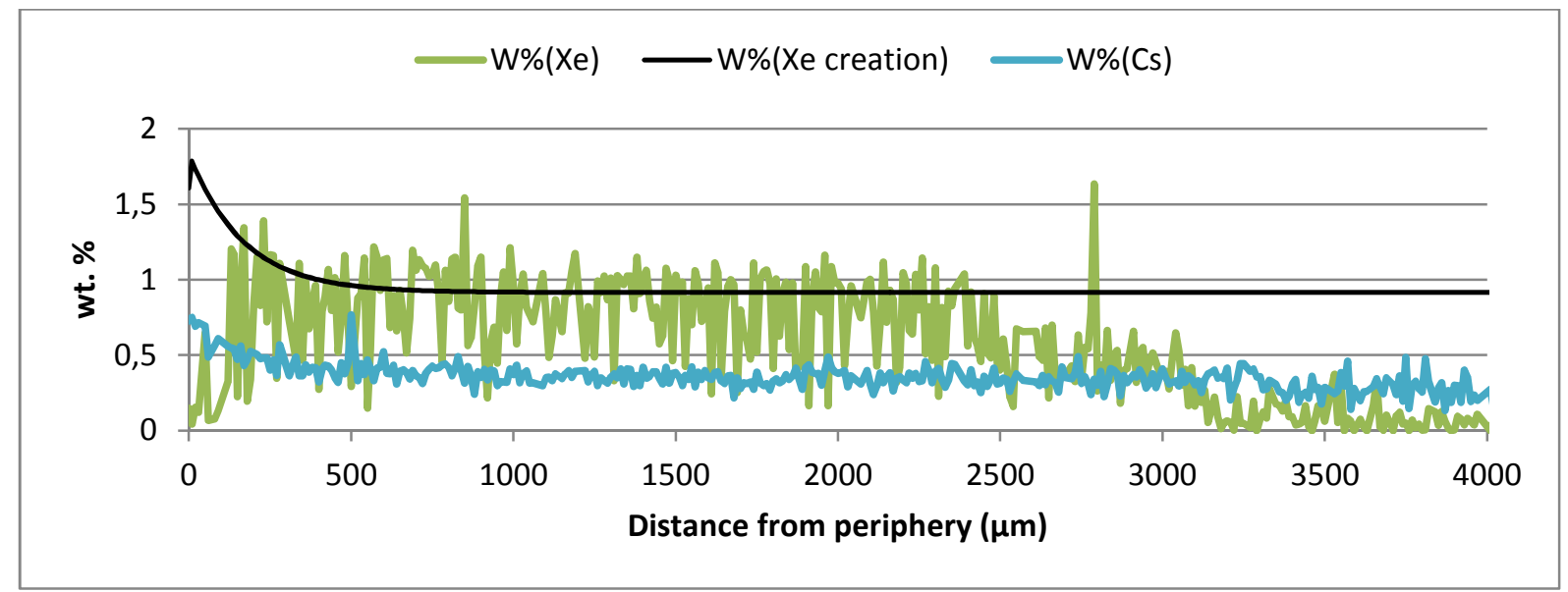

Figure 6: Xe and Cs radial EPMA quantitative profiles, VERDON-1 father rod

$\mathrm{Ba}$ and $\mathrm{Zr}$ concentrations are depicted on Figure 7. As most FP, their concentration is higher in the periphery of the fuel (around 0.64 and $1.15 \mathrm{wt} \%$ respectively) and decreases to around 0.2 and $0.58 \mathrm{wt} \%$ respectively $400 \mu \mathrm{m}$ away from the periphery. No particular association between $\mathrm{Ba}$ and $\mathrm{Zr}$ was observed contrary to what was expected, $\mathrm{BaZrO}_{3}$ being considered to be the most stable chemical state [5].

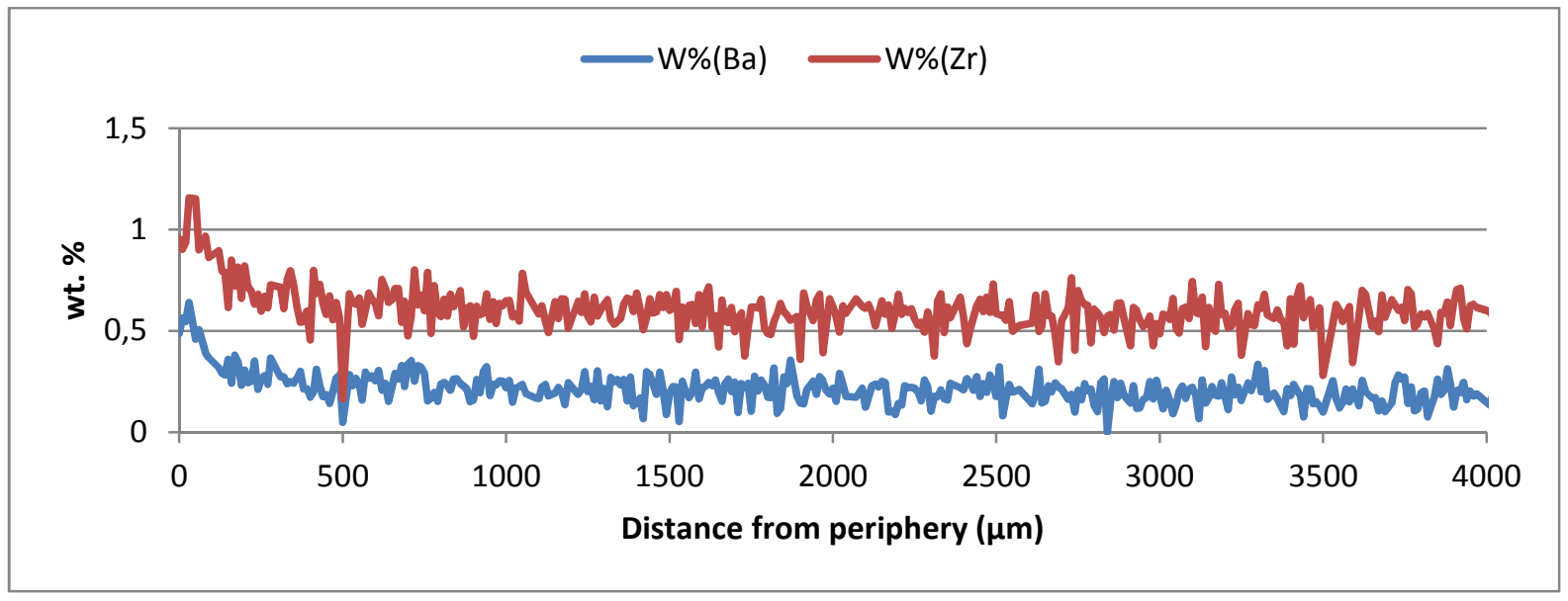

Figure 7: Ba and Zr radial EPMA quantitative profiles, VERDON-1 father rod

\subsection{The VERDON-1 sample}

The VERDON-1 sample was composed of two irradiated fuel pellets in their original M5 cladding selected from the former $\mathrm{UO}_{2}$ father rod. Two half pellets of un-irradiated depleted $\mathrm{UO}_{2}$ were placed at each end of the sample and held in place by crimping the cladding. The cladding was not fully sealed, allowing an interaction with the surrounding atmosphere. The VERDON-1 sample configuration before the test is presented on Figure 8 . The local burn-up of the fuel section was calculated to be $72 \mathrm{GWd}^{-\mathrm{t}_{\mathrm{U}}}{ }^{-1}$.

Before the test, the sample has been re-irradiated at low linear power $\left(10 \mathrm{~W} . \mathrm{cm}^{-1}\right)$ in OSIRIS material testing reactor (CEA Saclay) for about ten days. The objective was to recreate the short half-life FP such as ${ }^{99} \mathrm{Mo},{ }^{132} \mathrm{Te},{ }^{133} \mathrm{I},{ }^{131} \mathrm{I},{ }^{140} \mathrm{Ba}$, etc. 


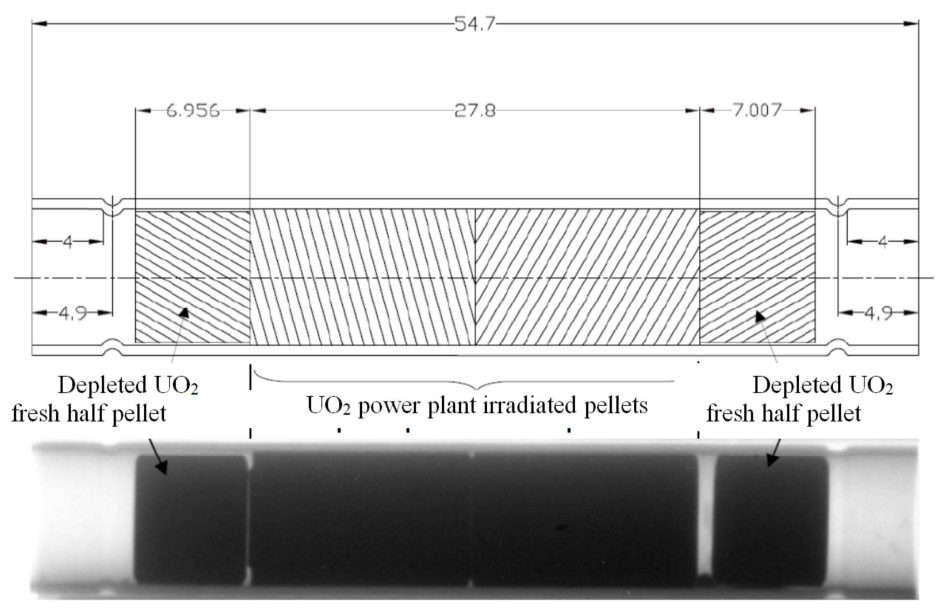

Figure 8: The VERDON-1 sample

\section{EXPERIMENTAL METHOD}

\subsection{VERDON-1 thermal-hydraulic sequence}

The experimental loop has been extensively described in [1], [7]-[12] so only the main characteristics are recalled in this section.

The release configuration of the VERDON-1 loop consists mainly of an induction furnace where the sample is heated, a fluid injection system $\left(\mathrm{He}, \mathrm{H}_{2}\right.$, steam, air ...), an aerosol filter to trap FP under aerosol forms, a May-Pack filter to trap gaseous iodine species, a condenser to recover steam and a final safety filter. Three on-line $\gamma$-spectrometry stations enable release and deposit kinetics measurements during the thermal-hydraulic sequence.

The VERDON-1 test was carried out 64 hours after the re-irradiation of the fuel. Its thermal-hydraulic sequence consisted in three main phases which differ by the composition of the atmosphere (Figure 9):

- The first phase was a $400^{\circ} \mathrm{C}$ plateau maintained during one hour under neutral atmosphere;

- The second phase began around $750^{\circ} \mathrm{C}$ under mixed steam- $\mathrm{H}_{2}$ oxidizing atmosphere. The steam and $\mathrm{H}_{2}$ injection flow rates $(25 \mathrm{mg} / \mathrm{s}$ and $0.45 \mathrm{mg} / \mathrm{s}$ respectively) were maintained during nearly one hour at $1500^{\circ} \mathrm{C}$ in order to reach complete cladding oxidation;

- A reducing atmosphere was imposed in phase 3 , from $1500^{\circ} \mathrm{C}$ to the end of the test with a molar ratio $\mathrm{H}_{2} / \mathrm{H}_{2} \mathrm{O}$ of 10 . The very end of phase 3 (from $2400^{\circ} \mathrm{C}$ to $2500^{\circ} \mathrm{C}$ ) was performed with a decreasing $\mathrm{H} 2$ flow rate and finally, water injection was stopped during the last part of the test (up to $2600^{\circ} \mathrm{C}$ ). The atmosphere was thus variable from reducing to neutral at the end of the test. The end of the sequence was defined by the first of these two criteria: the detection of the fuel sample relocation or a maximal temperature of $2600^{\circ} \mathrm{C}$. No apparent relocation has been detected so the end of the sequence (shut down of HF power supply) was performed when the maximal temperature of $2600^{\circ} \mathrm{C}$ was reached. 


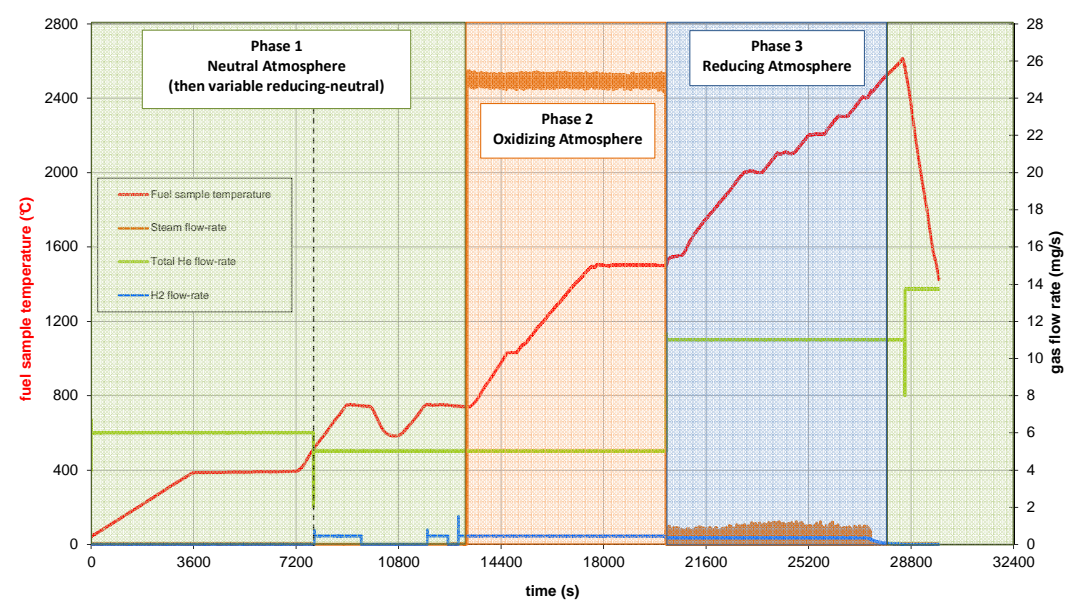

Figure 9: VERDON-1 thermal-hydraulic sequence

After the test, the fuel sample was recovered from the furnace. Though the fuel degradation was quite advanced indicating an imminent relocation of the fuel, both irradiated pellets had almost kept their original geometry (Figure 10). The sample was brittle as a consequence of the test and a partial melting of the fuel pellets and some missing pieces were observed. As indicated in Table 1, the two original pellets measured together $27.8 \mathrm{~mm}$ length, with a mean diameter of $8.086 \mathrm{~mm}$. After the test, the length of the fuel element was approximately $31 \mathrm{~mm}$ with a diameter of $8.6 \mathrm{~mm}$. This swelling is due to the increase of internal pressure and mechanical strains caused by the thermal-hydraulic sequence. This is probably the origin of the cracks observed into the fuel.

\subsection{Characterizations setup}

After the test, the two irradiated fuel pellets were separated. Each pellet was prepared in a different way: sample A was embedded in a Wood metallic alloy (Bi/Sn) and sample B in Epoxy resin. The samples in their respective embedding were polished up to the half of their diameter.

OM observations were performed using a LEICA DM RXA2 device adapted for hot cell work. Image acquisition was done with a LEICA DFC 320 camera on the SIS acquisition system.

SEM observations were performed in secondary electron mode using a Philips XL30 device. Large field acquisitions were performed using the ADDA SIS system and the AnalySIS software was used for images analyses.

Concerning EPMA, a shielded CAMECA SX100R device was used for acquisition and exploitation of the measurements. Incident electron beam characteristics were set at $20 \mathrm{kV}$ and $200 \mathrm{nA}$.

In order to perform SEM analyses on sample B, a carbon coating was required to improve its electric conductivity. Though given their brittleness half a pellet was destroyed during the cutting process. Samples A and B were submitted to post-test examinations in the LECA-STAR facility (CEA Cadarache). SEM and EPMA were performed on sample A and a 
complete metallographic analysis (optical microscope) was made on sample B, as well as SEM analyses. Only the most representative images obtained by each technique are presented below. Their location in the samples is presented on the macrographs of samples A and B (Figure 10).
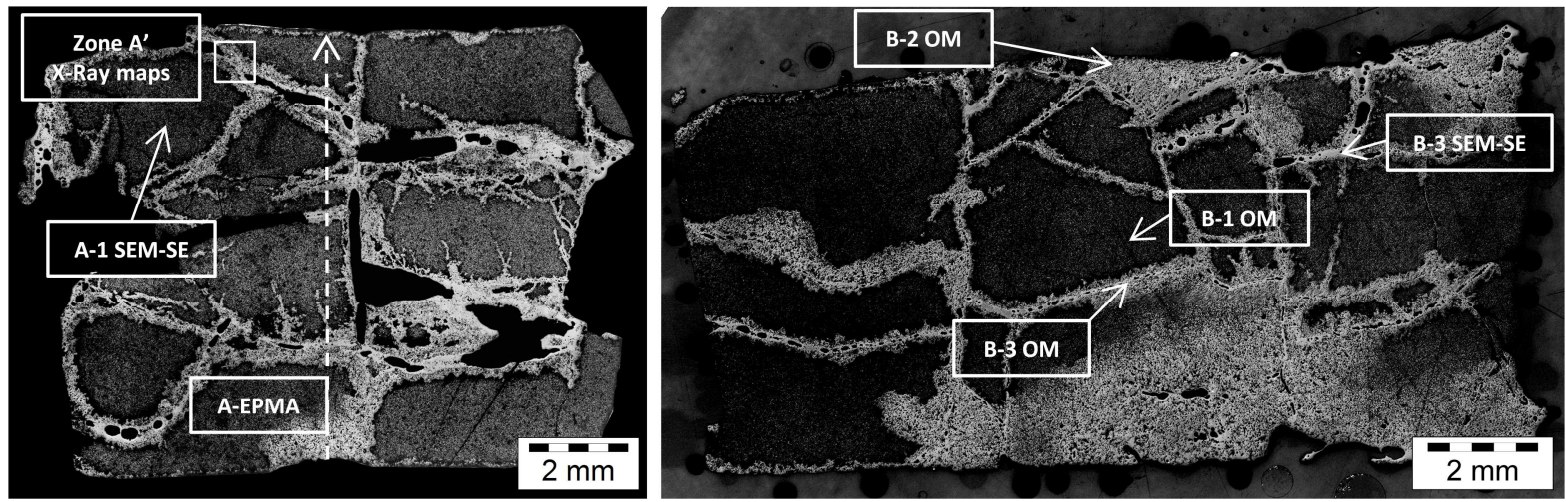

Figure 10: Micrograph of the VERDON-1 fuel pellets after the test, Sample A (left) and Sample B (right) after preparation

\section{RESULTS}

\subsection{Microstructure analyses}

On these macrographs, an advanced state of degradation of the samples can be observed. This means that the relocation of the fuel was imminent at the end of the VERDON-1 test. Three main areas are observed on the Figure 10:

- A predominant dark-grey zone with elevated porosity,

- A light-grey one with moderated porosity,

- A second light-grey phase with reduced porosity.

Representative images of these 3 regions are presented on Figure 11. The elevated-porosity region is characterized by an elevated number of small round pores and big irregular ones. These last may have been produced by the coalescence of the smallest ones. Furthermore, many white precipitates are present in the regions of elevated and moderated porosity. Regarding to the region of reduced porosity, a few big size precipitates were found (see the X-ray map on Figure 14).

A detailed image analysis gave the size distribution of pores and white precipitates in the different regions and their contribution to the surface. The surface contribution of the pores in the elevated porosity region almost doubles compared to the moderated porosity one: $42 \%$ and $25 \%$ respectively. Almost all the porosity is due to pores of size superior to $4 \mu \mathrm{m}$, in both regions. The total number of pores smaller than $4 \mu \mathrm{m}$ is four times more important in the elevated porosity region than in the moderated porosity one.

Regarding the white precipitates, their contribution to the total surface is almost the same in the moderated porosity region than in the elevated porosity one: around 0.5 and $0.4 \%$, respectively. The precipitates observed in the elevated porosity region are slightly 
smaller, with a mean Equivalent Circle Diameter (ECD) of $0.8 \mu \mathrm{m}$, than those from the moderated porosity region, with an ECD of $1.1 \mu \mathrm{m}$.

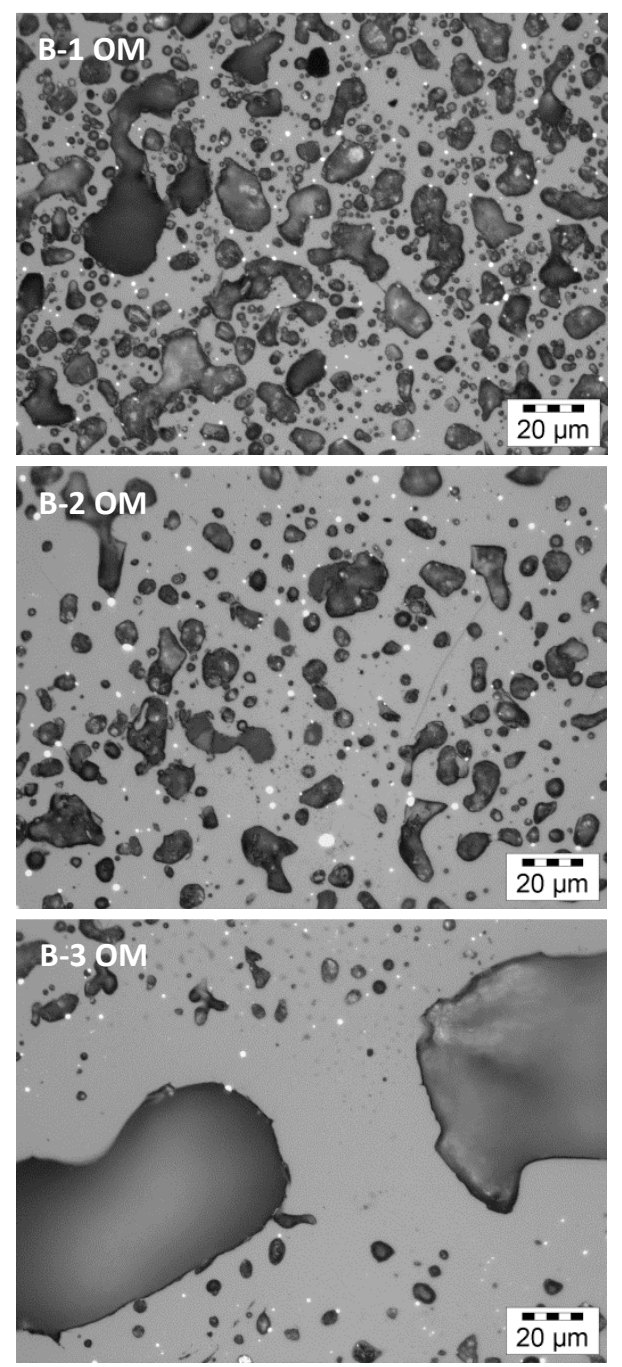

Figure 11: Optical Microscopy of region of elevated (B-1 OM), moderated (B-2 OM) and low porosity (B-3 OM), sample B

Secondary electrons SEM (SE-SEM) images representative of the elevated and low porosity regions in samples A and B are presented on Figure 12. Fuel grains were clearly identified inside the pores of both regions, where also small round precipitates were observed. These precipitates, corresponding to the white precipitates observed by optical microscopy, have a size ranging between 1.9 and $3.2 \mu \mathrm{m}$. They are similar to those already observed in the father rod identified as metallic precipitates of Mo, $\mathrm{Pd}$ and $\mathrm{Ru}$, but bigger. 


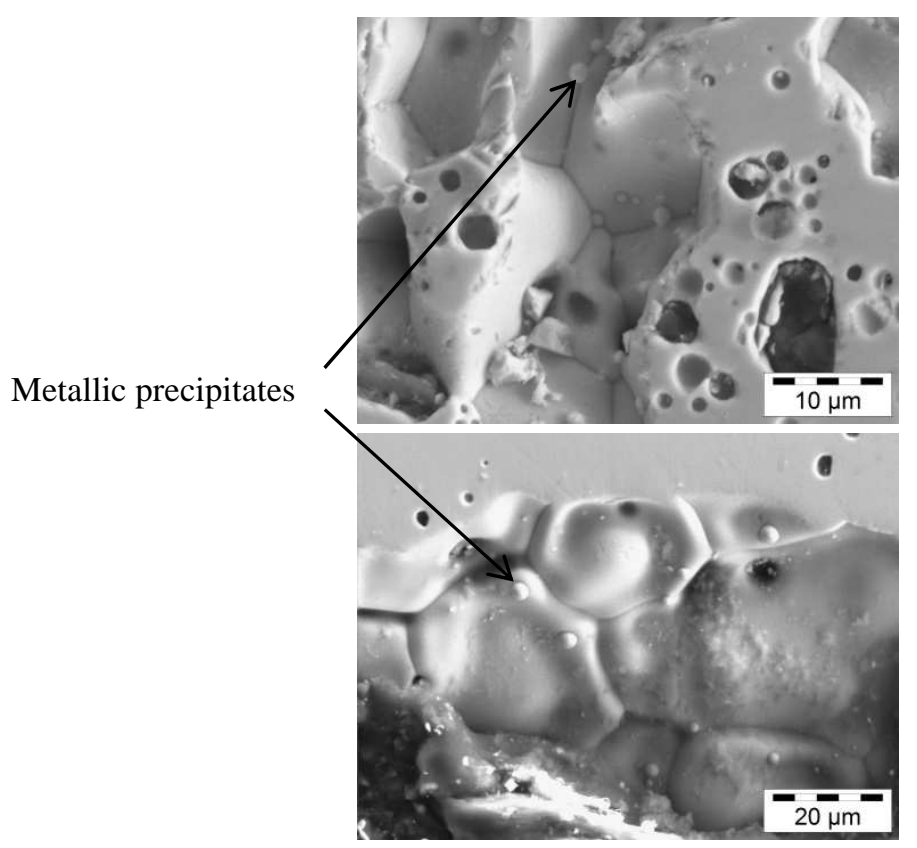

Figure 12: SEM-SE, Region of elevated (A-1 SEM-SE) and reduced porosity (B-3 SEM-SE), Samples A and B

\subsection{Chemical analyses}

EPMA were performed on Sample A, as indicated on Figure 10 (radial dashed line). In this paper, the results of the transversal analyses are presented, since no particular radial or longitudinal concentration tendencies have been observed.

As observed on Figure 13, an important quantity of $\mathrm{Zr}$ was found in the reduced porosity regions. This result highlights the chemical difference between the elevated, moderated and low porosity regions: the lower the porosity, the higher the zirconium content.

A slight increase in $\mathrm{Pu}$ and $\mathrm{Nd}$ concentrations in the reduced porosity regions could be noticed, corresponding to the concentration profile of $\mathrm{Zr}$. In the high porosity region, $\mathrm{Pu}$ and $\mathrm{Nd}$ concentrations were not modified after the test (Figure 13). On the contrary, $\mathrm{Pu}$ and $\mathrm{Nd}$ concentrations in the periphery decreased compared to that observed in the father rod quantitative analyses (Figure 2). 

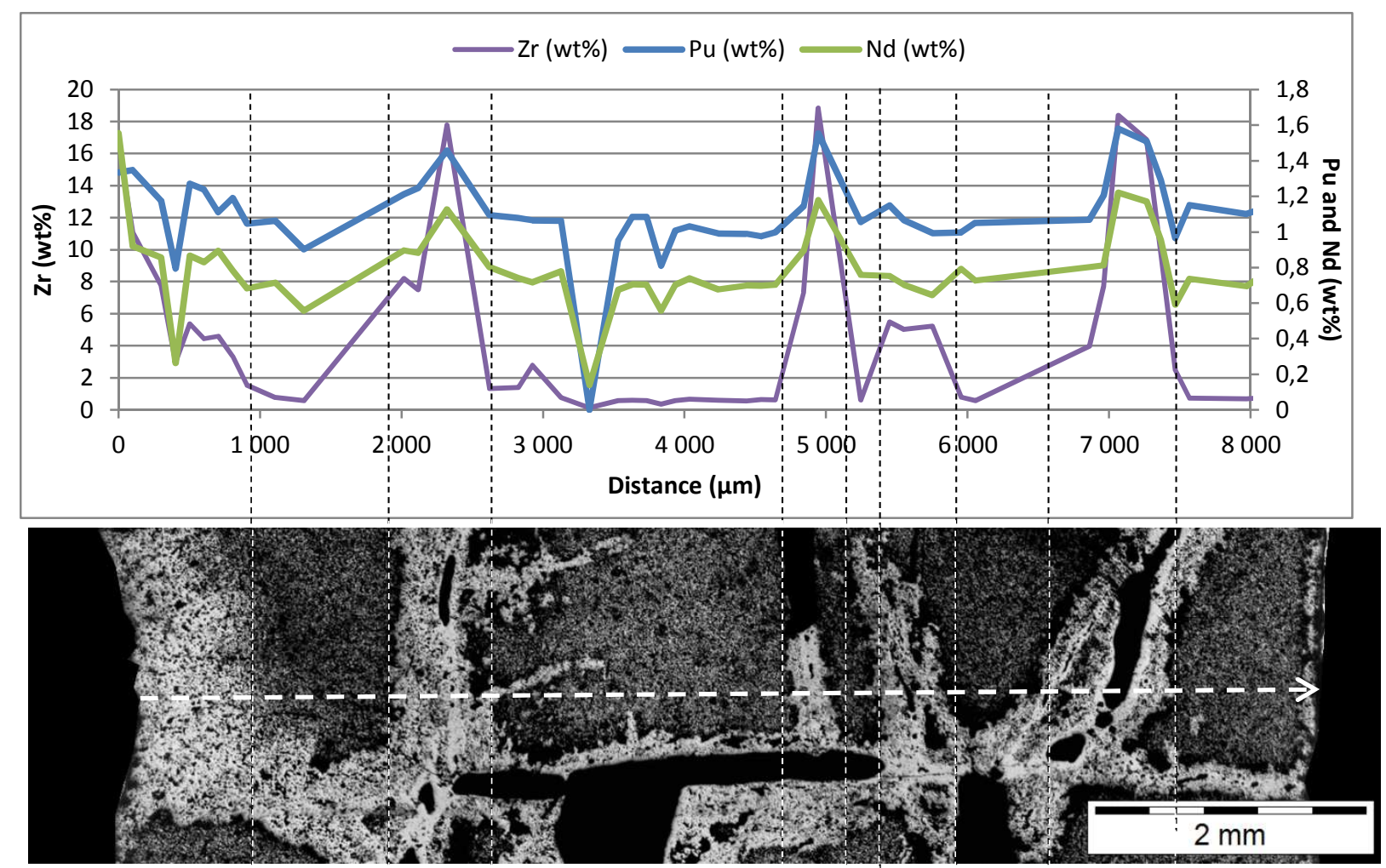

Figure 13 : Zr, Ba, Pu and Nd transversal EPMÁ quantitative profiles, sample A-EPMA

Zone A' on Figure 10 was chosen to perform X-ray maps because the three regions of elevated, moderated and reduced porosity were present. Images of Zone A' presented on Figure 14 correspond to a SE image and $\mathrm{U}, \mathrm{Zr}, \mathrm{O}, \mathrm{Ba}, \mathrm{Ru}$, Mo and Tc X-ray maps.
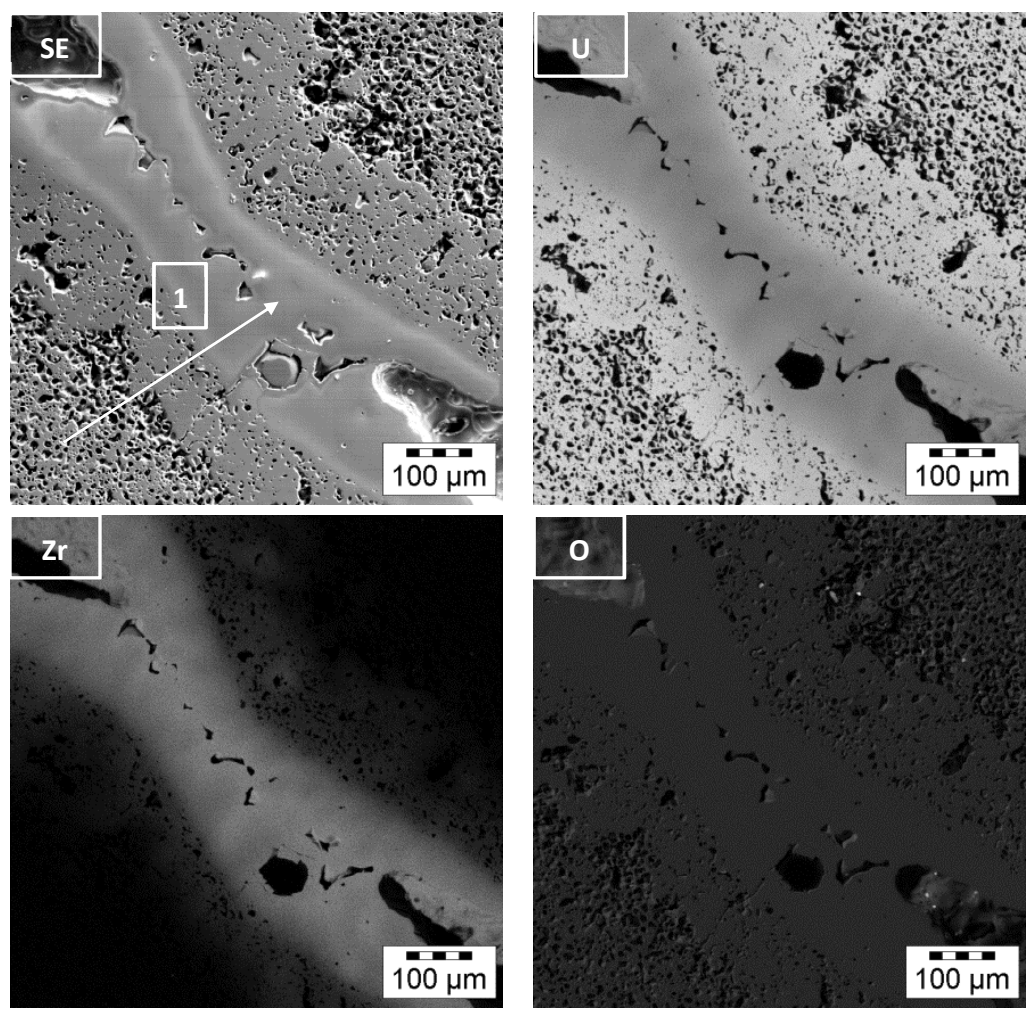

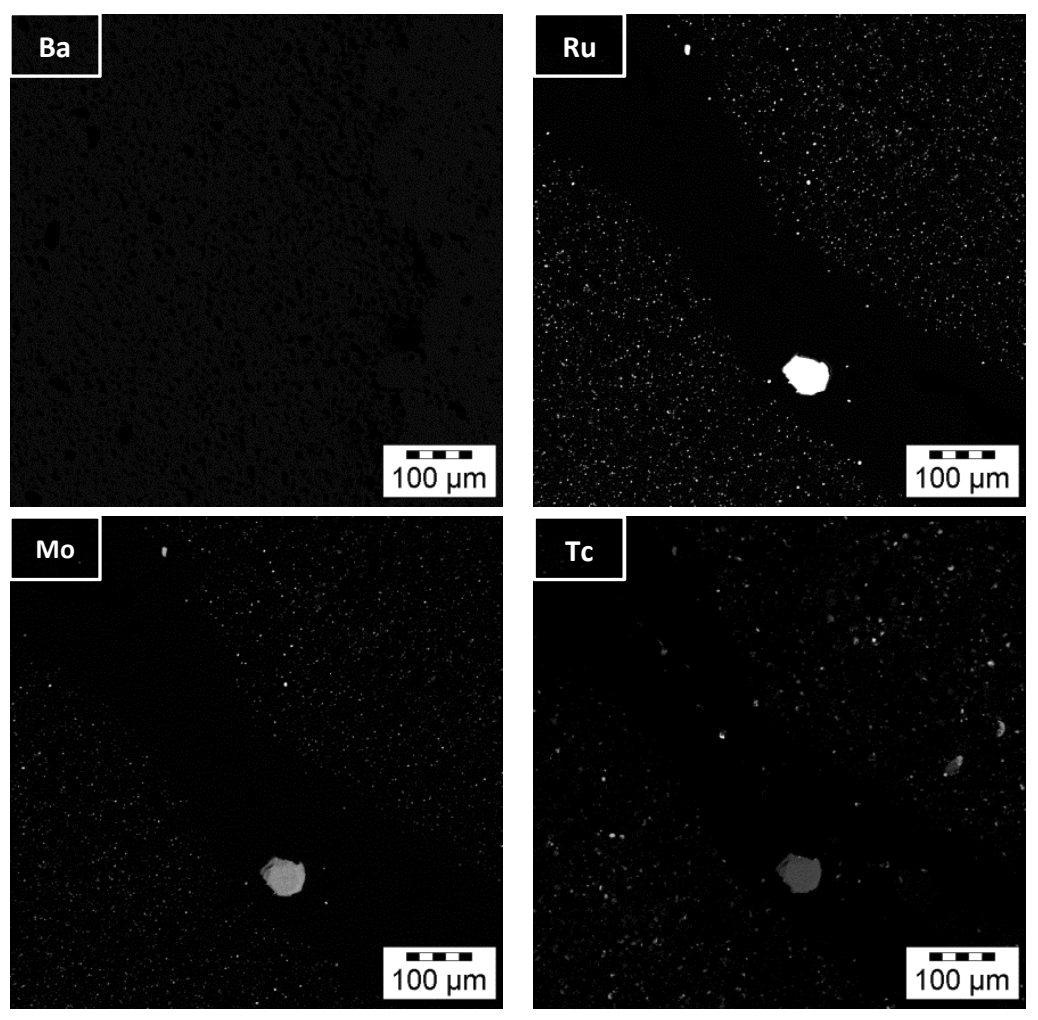

Figure 14: U, Zr, O, Ba, Ru, Mo, and Tc X-ray maps, Zone A’ Sample A

$\mathrm{Ru}, \mathrm{Mo}$ and Tc are observed in the same precipitates. However, it is important to notice that $\mathrm{Bi}$ which is one of the metallic embedding components used in the preparation of this sample can interfere with Tc signal.

In accordance with the previous EPMA results, the region which presented the lowest quantity of pores was highly concentrated in $\mathrm{Zr}$ while the $\mathrm{U}$ content seems to be reduced compared to the most porous regions. To quantify this phenomenon, EPMA has been performed along the line scan 1 (Figure 14) crossing the three regions. This line started in the most porous region and ended in the center of the region highly concentrated in $\mathrm{Zr}$ without pores. The main results of this analysis are displayed on Figure 15.
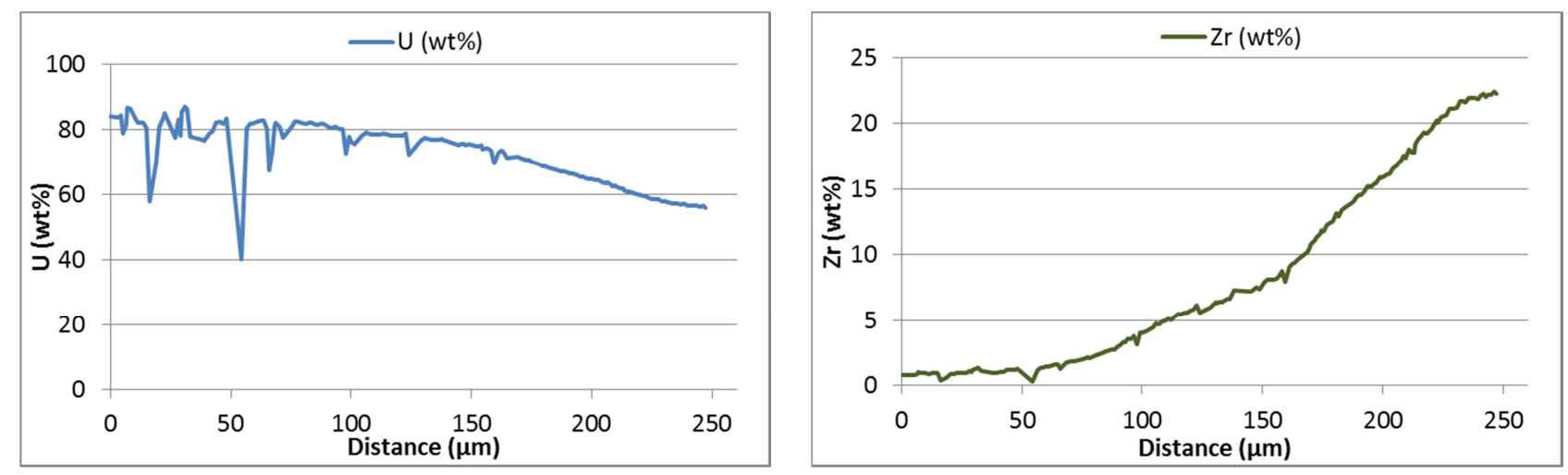

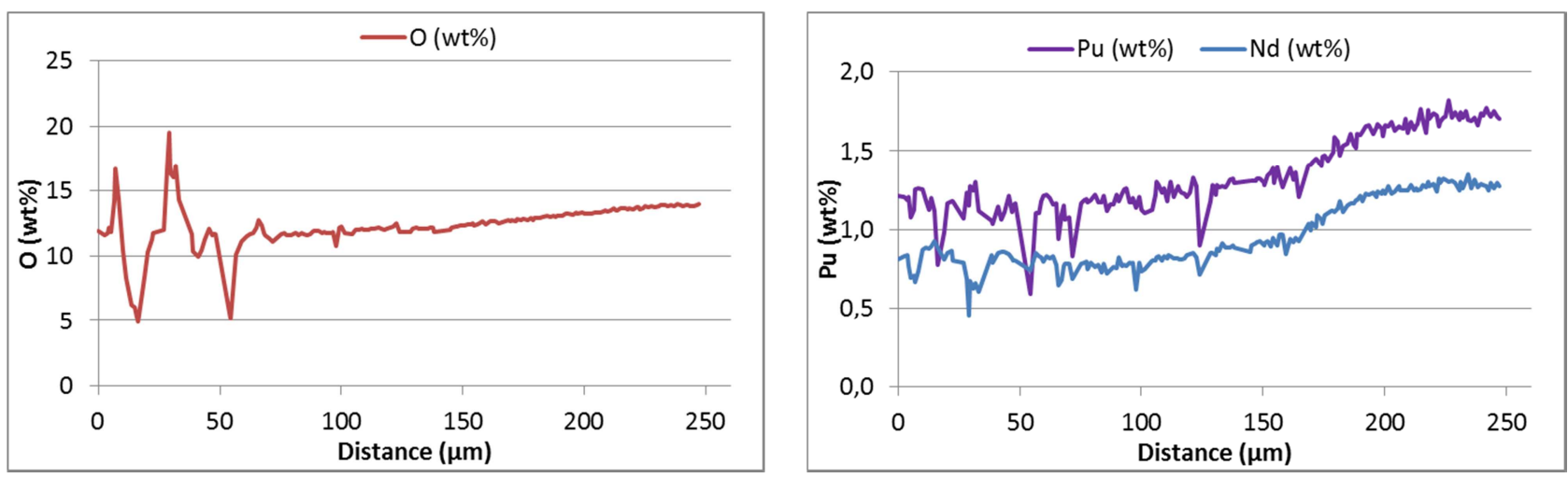

Figure 15: U, Zr, O, Pu and Nd EPMA quantitative analyses. Line scan 1 in Zone A' Sample A

According to the profiles observed on Figure 15, U concentration was around $85 \mathrm{wt} \%$, in the elevated porosity zone and gradually decreases down to $75 \mathrm{wt} \%$ in the moderated porosity region. Once in the reduced porosity region, it drops to $55 \mathrm{wt} \%$. Regarding $\mathrm{O}$, its concentration increases from $11.8 \mathrm{wt} \%$ in the high porosity region up to about $14 \mathrm{wt} \%$ in the center of the reduced porosity one. The same behavior is observed for $\mathrm{Zr}$ and $\mathrm{Pu}$ which concentrations increases from about 1 and $1.2 \mathrm{wt} \%$ to about 23 and $1.7 \mathrm{wt} \%$ in the center of the crack, respectively.

These results were also confirmed by quantitative analyses performed along the A2EPMA and A2'-EPMA lines (Figure 10). In two regions of moderated porosity located at the periphery of the fuel pellet originally in contact with the cladding. $\mathrm{Zr}$ concentration is elevated and a high content of $\mathrm{Pu}$ is also present.

\section{DISCUSSION ON U-ZR INTERACTION}

The post-test examination of the VERDON-1 sample has highlighted a change of microstructure after the test. Three zones have been observed with different porosity. Lowporosity regions are rich in $\mathrm{Zr}$ and $\mathrm{Pu}$ and depleted in $\mathrm{U}$ which is characteristic of a $\mathrm{U}-\mathrm{Zr}$ interaction.

To go further in the understanding of this phenomenon, a sample composed of an irradiated fuel pellet in its original M5 cladding was selected from the same $\mathrm{UO}_{2}$ father rod as the VERDON-1 sample. It was submitted to an annealing treatment consisting in two temperature plateaus at 300 and $1200^{\circ} \mathrm{C}$ during 15 minutes and a third one at $1500^{\circ} \mathrm{C}$ during 25 minutes under reducing atmosphere $\left(\mathrm{Ar}+4 \% \mathrm{H}_{2}\right)$. The test was carried out in the MERARG experiment loop [10]. After the annealing test, the sample ("intermediate state sample" in the following) was embedded in an epoxy resin and polished down to half his diameter.

The evolution of the porosity into the fuel clearly indicates that the pores interconnection process began around $1500^{\circ} \mathrm{C}$ and was enhanced as the temperature increased (Figure 16). This phenomenon could explain the main burst release observed for $\mathrm{Xe}$ and $\mathrm{Kr}$ during the oxidation plateau. Indeed, as the pores interconnected, paths were created in the 
whole sample for gaseous FP to diffuse more rapidly in the sample and release from the fuel [13].

An evolution of the $\mathrm{ZrO}_{2}$ layer can also be observed as it comes closer and interact with the fuel when the temperature increases.
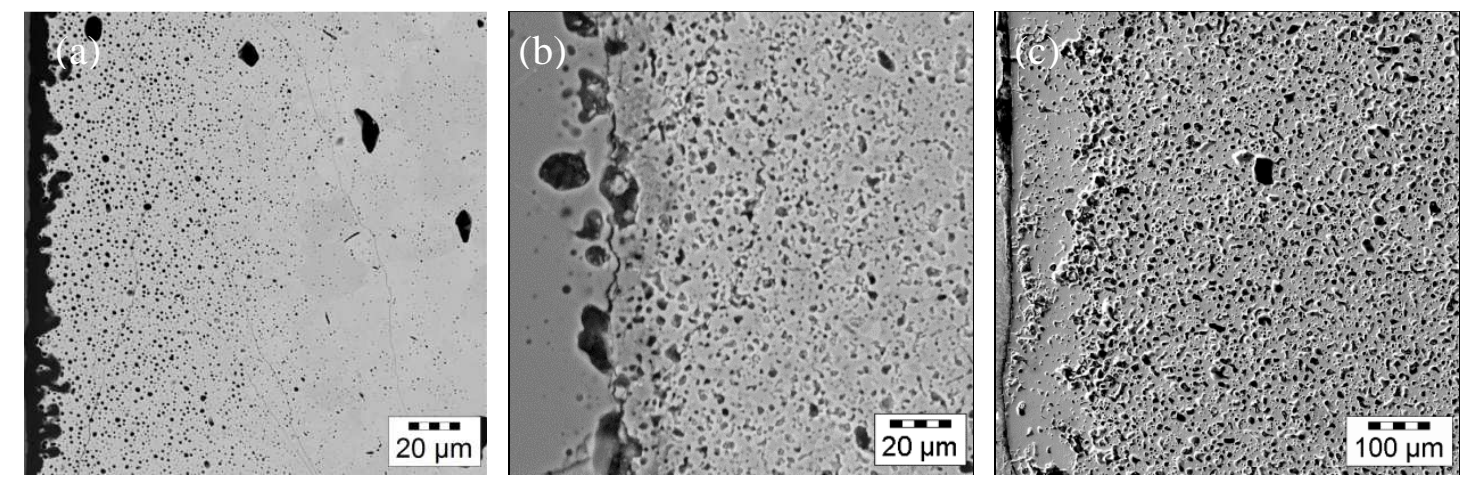

Figure 16 : SEM images of the periphery of the (a) father rod sample (BSE), (b) the intermediate state sample (BSE) and (c) the VERDON-1 sample (SE)

Quantitative results and X-ray maps indicated that there was indeed an interaction between $\mathrm{Zr}$ from the oxidized cladding and $\mathrm{UO}_{2}$ from the fuel: a $(\mathrm{U}-\mathrm{Zr}) \mathrm{O}_{2}$ mix melted and penetrated through the cracks and the pores, carrying FP present in the periphery of the fuel (HBS structure). This would explain the elevated concentrations of $\mathrm{Pu}$ and $\mathrm{Nd}$ observed in the moderated and reduced porosity regions. The behavior of these two non-volatile FP agrees with the results of VERCORS test [12], [14], [15].

In order to determine whether $\mathrm{ZrO}_{2}$ melted under VERDON-1 test conditions or a $\mathrm{ZrO}_{2}-\mathrm{UO}_{2}$ or $\mathrm{Zr}-\mathrm{UO}_{2}$ interaction took place, thermodynamic estimations were made. As indicated in Part 3.1, during the third stage of the test, the fuel sample was submitted to a reducing atmosphere consisting of a $\mathrm{H}_{2} / \mathrm{H}_{2} \mathrm{O}$ mixture with a molar ratio $10: 1$, up to $2400^{\circ} \mathrm{C}$. Assuming that the fuel was in equilibrium with the atmosphere and thus its oxygen potential $\mu \mathrm{O}_{2}$ was imposed by it, the Wheeler and Jones equation can be used [16]:

$$
\mu \mathrm{O}_{2}[\mathrm{~J} / \text { mol. } \mathrm{K}]=-479070+4.184 \times T\left[8.86 \log (T)-4.42+9.152 \log \left(\frac{\mathrm{PH}_{2} \mathrm{O}}{\mathrm{PH}_{2}}\right)\right]
$$

Considering the experimental values, $\mu \mathrm{O}_{2}=-291 \mathrm{~kJ} \cdot \mathrm{mol}^{-1} \cdot \mathrm{K}^{-1}$ was obtained. According to the Ellingham diagram [5] presented on Figure 17, the reduction of $\mathrm{ZrO}_{2}$ to $\mathrm{Zr}$ would take place at less than $-600 \mathrm{~kJ} . \mathrm{mol}^{-1}$ for a temperature of $2400^{\circ} \mathrm{C}$. This means that the reducing character of the VERDON-1 test atmosphere was not strong enough to reduce the oxidized cladding.

Since the maximal temperature at the end of the test was lower that the pure $\mathrm{ZrO}_{2}$ melting temperature (around $2720^{\circ} \mathrm{C}$ ), an interaction $\mathrm{ZrO}_{2}-\mathrm{UO}_{2}$ may have taken place. A similar behavior has already been observed in the VERCORS program, where the fuel collapsed at temperatures $230^{\circ} \mathrm{C}$ lower than the expected $\mathrm{UO}_{2}$ melting temperature [12]. According to the pseudo binary $\mathrm{ZrO}_{2}-\mathrm{UO}_{2}$ phase diagram presented on Figure 18, extracted from [17], an indifferent point (the analogue to liquid-vapor azeotrope) exists at a molar fraction of $\mathrm{x}_{\mathrm{ZrO} 2}=0.58$. Quantitative analyses performed after the test helped determining the 
concentration of $\mathrm{U}, \mathrm{Zr}$ and $\mathrm{O}$ at the center of one crack. The molar fractions measured were $0.168 ; 0.183$ and 0.636 , for $\mathrm{U}, \mathrm{Zr}$ and $\mathrm{O}$ respectively. They have been calculated from the measured mass fractions considering a phase containing $\mathrm{Zr}, \mathrm{U}, \mathrm{O}, \mathrm{Pu}$ and $\mathrm{Nd}$. With these results a $\mathrm{Zr} /(\mathrm{U}+\mathrm{Zr})$ ratio of 0.52 which is not far from the indifferent point composition, was obtained. Its melting temperature $\left(2580^{\circ} \mathrm{C}\right)$ and the temperature reached by the end of the VERDON-1 test $\left(2600^{\circ} \mathrm{C}\right)$ were close enough to form a liquid solution.

XRD experimental data, not shown in this paper, seemed to agree with this composition.

Thus, it is assumed that a reaction between $\mathrm{UO}_{2}$ and $\mathrm{ZrO}_{2}$ from the cladding took place. When a composition matching (or close to) the indifferent point was attained, the solution melted and penetrated into the pellets through the cracks, carrying FP normally located in the HBS, such as Pu and Nd.

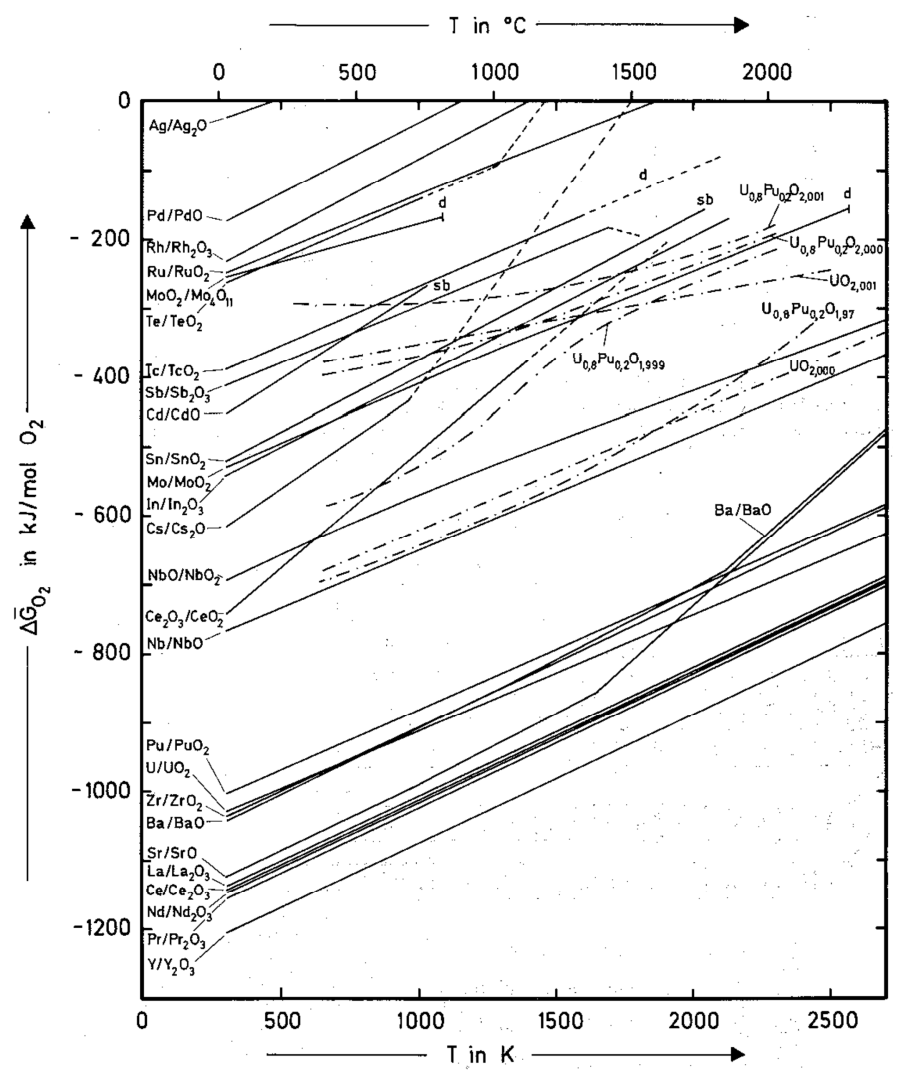

Figure 17: Ellingham Diagram [5] 


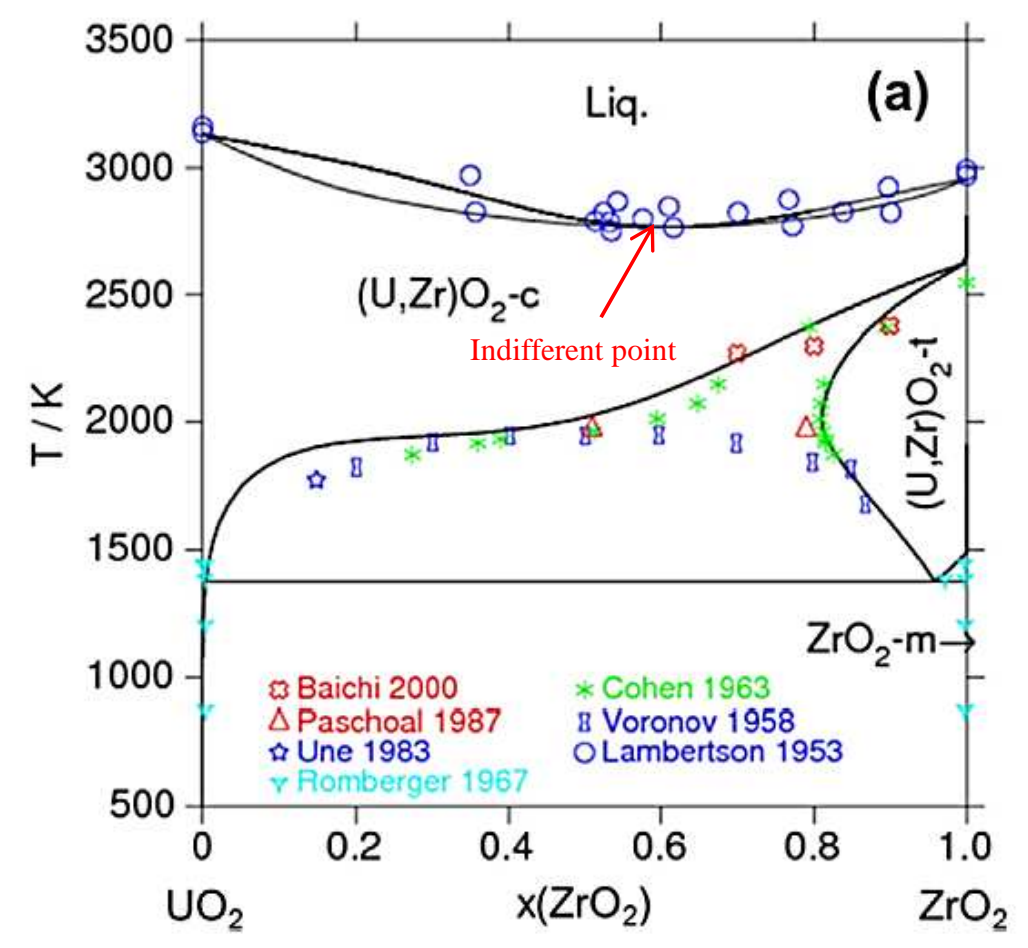

Figure 18: Phase diagram for the pseudo binary $\mathrm{UO}_{2}-\mathrm{ZrO}_{2}[18]$

\section{CONCLUSION}

The VERDON-1 test was devoted to high burn-up $\mathrm{UO}_{2}$ fuel behavior and FP release under reducing conditions at very high temperature (up to $2610^{\circ} \mathrm{C}$ ). The sample recovered after the VERDON-1 test was characterized using OM, SEM and EPMA techniques. An intermediate test has been performed under reducing atmosphere up to $1500^{\circ} \mathrm{C}$ in the MERARG experimental loop. An irradiated fuel sample, obtained from the same father rod as the VERDON-1 sample was used in this test and has been characterized. This was the first time that these types of analyses were performed at the CEA Cadarache on a sample submitted to severe accidents conditions.

Characterizing the chemical phases in the fuel and their evolution allows understanding both the fuel and FP behavior during a severe accident. These results can be used for the improvement of mechanistic codes (such as the MFPR code developed by the IRSN) which would enable a better assessment of the source term for a severe accident.

The comparison between the intermediate state sample and VERDON-1 sample tends to prove that pores interconnection took place around $1500^{\circ} \mathrm{C}$ and end to the formation of three different regions: (1) a first region presenting an elevated density of irregular interconnected pores and small precipitates, (2) a second region presenting a moderated density of pores and also small precipitates, and (3) a third region presenting a low porosity with big size pores and a few isolated big size precipitates. These three regions differed greatly in the $\mathrm{Zr}$ content, increasing as the porosity decreases. At the same time, $\mathrm{Pu}$ and $\mathrm{Nd}$ presented similar concentrations profile than those of $\mathrm{Zr}$. 
From these results, the following evolution is assumed to have taken place during the VERDON-1 test. First, the swelling of the samples due to an increase of internal pressure and mechanical stresses caused by the thermal-hydraulic sequence produced many cracks into the fuel. Being in contact with the pellet, $\mathrm{ZrO}_{2}$ from the oxidized cladding diffused into the fuel attaining concentrations close to the eutectic point of the pseudo binary $\mathrm{UO}_{2}-\mathrm{ZrO}_{2}$ system. It melted at the end of the test and penetrated into the fuel through the cracks. Many heavy elements that were located in the periphery of the pellet (such as $\mathrm{Pu}$ and $\mathrm{Nd}$ ) were also dissolved and transported into the melt. $\mathrm{ZrO}_{2}$ and other elements kept diffusing into the fuel matrix, leading to the three microstructures observed at the end of the test.

Further characterizations of the VERDON-1 sample are presented in the third part of this article [13]. These analyses are focused on the evolution of FP inside the fuel during the VERDON-1 test.

\section{AKNOWLEDGEMENT}

This work was performed in the frame work of a collaboration including the CEA, EdF and IRSN. The authors are indebted to T. Blay, L. Brunaud, P. Delion, L. Fayette, K. Hanifi, J. Noirot, S. Reboul and I. Zacharie-Aubrun from the LEMCI's teams working in the CEA LECA-STAR hot-cells facility at Cadarache, for their huge contribution to this work. We also greatly thank S. Clément, M. Pontillon and G. Volle for their work on the MERARG loop.

\section{REFERENCES}

[1] Y. Pontillon, E. Geiger, C. Le Gall, S. Bernard, A. Gallais-During, P. P. Malgouyres, E. Hanus, and G. Ducros, "Fission products and nuclear fuel behavior under severe accident conditions - Part 1: Main lessons learnt from the first VERDON test," Journal of Nuclear Materials, Submitting.

[2] J. Noirot, L. Desgranges, and J. Lamontagne, "Detailed characterisations of high burn-up structures in oxide fuels," Journal of Nuclear Materials, vol. 372, no. 2-3, pp. 318-339, Jan. 2008.

[3] H. Matzke and J. Spino, "Formation of the rim structure in high burnup fuel," Journal of Nuclear Materials, vol. 248, pp. 170-179, Sep. 1997.

[4] J. Spino, K. Vennix, and M. Coquerelle, "Detailed characterisation of the rim microstructure in PWR fuels in the burn-up range 40-67 GWd/tM," Journal of Nuclear Materials, vol. 231, no. 3, pp. 179-190, Aug. 1996.

[5] H. Kleykamp, "The chemical state of the fission products in oxide fuels," Journal of Nuclear Materials, vol. 131, no. 2-3, pp. 221-246, 1985.

[6] T. Blay, I. Roure, and J. Lamontagne, "FX0GAC/E04/4034 - Examen au MEB et à la microsonde d'un combustible REP UO2 ALIX irradié 6 cycles dans GRAVELINES 5," CEA Cadarache, Note technique DEC/SA3C/03-121, 2003.

[7] G. Ducros, S. Bernard, M. P. Ferroud-Plattet, and O. Ichim, "Use of Gamma spectrometry for measuring fission product releases during a simulated PWR severe accident: Application to the VERDON experimental program," presented at the ANIMA, 2009, pp. 1-7.

[8] A. Gallais-During, J. Bonnin, P.-P. Malgouyres, S. Bernard, Y. Pontillon, E. Hanus, and G. Ducros, "VERDON Laboratory: Performances of the Experimental LWR Severe Accident Device and Fisrt Results of Fission Products Release on High Burn-up UO2 fuel," presented at the 21st International Conference Nuclear Energy for New Europe, Ljubjana, 2012.

[9] A.Gallais-During, J. Bonnin, P.-P. Malgouyres, S. Morin, S. Bernard, B. Gleizes,Y. Pontillon, E. Hanus, G. Ducrosa, "Performance and first results of fission product release and 
transportprovided by the VERDON facility," Nuclear Engineering and Design 277, CEA Cadarache, pp. 117-123, 2014.

[10] Y. Pontillon, J. Bonnin, E. Addes, J. Cochaud, J. Piquemal, M. Pontillon, and C. Roure, "Fission gas release under normal and off-normal conditions: New analytical device implemented at the CEA Cadarache," presented at the European Working Group "Hot Laboratories and Remote handling" Plenary Meeting, Petten, Netherlands, 2005.

[11] A. Gallais-During, J. Bonnin, P.-P. Malgouyres, S. Morin, S. Bernard, B. Gleizes, Y. Pontillon, E. Hanus, and G. Ducros, "Performance and first results of fission product release and transport provided by the VERDON facility," Nuclear Engineering and Design, vol. 277, pp. 117-123, Oct. 2014.

[12] Y. Pontillon, G. Ducros, and P. P. Malgouyres, "Behaviour of fission products under severe PWR accident conditions VERCORS experimental programme-Part 1: General description of the programme," Nuclear Engineering and Design, vol. 240, no. 7, pp. 1843-1852, Jul. 2010.

[13] C. Le Gall, E. Geiger, Y. Pontillon, A. Gallais-During, J. Lamontagne, E. Hanus, and G. Ducros, "Fission products and nuclear fuel behavior under severe accident conditions - Part 3: Fission products speciation in the VERDON-1 sample," Journal of Nuclear Materials, Submitting.

[14] Y. Pontillon and G. Ducros, "Behaviour of fission products under severe PWR accident conditions: The VERCORS experimental programme-Part 2: Release and transport of fission gases and volatile fission products," Nuclear Engineering and Design, vol. 240, no. 7, pp. 1853-1866, Jul. 2010.

[15] Y. Pontillon and G. Ducros, "Behaviour of fission products under severe PWR accident conditions. The VERCORS experimental programme-Part 3: Release of low-volatile fission products and actinides," Nuclear Engineering and Design, vol. 240, no. 7, pp. 1867-1881, Jul. 2010.

[16] V. J. Wheeler and I. G. Jones, "Thermodynamic and composition changes in UO2 $\pm x(x<$ 0.005 ) at $1950 \mathrm{~K}$," Journal of Nuclear Materials, vol. 42, no. 2, pp. 117-121, Feb. 1972.

[17] P. Piluso, G. Trillon, and C. Journeau, "The UO2-ZrO2 system at high temperature ( $\mathrm{T}>$ $2000 \mathrm{~K}$ ): importance of the meta-stable phases under severe accident conditions," Journal of Nuclear Materials, vol. 344, no. 1-3, pp. 259-264, Sep. 2005.

[18] A. Quaini, C. Guéneau, S. Gossé, B. Sundman, D. Manara, A. L. Smith, D. Bottomley, P. Lajarge, M. Ernstberger, and F. Hodaj, "High temperature investigation of the solid/liquid transition in the PuO2-UO2-ZrO2 system," Journal of Nuclear Materials, vol. 467, Part 2, pp. 660-676, Dec. 2015. 